\begin{abstract}
Iranica
Abstracta Iranica Revue bibliographique pour le domaine irano-aryen

Volume 34-35-36 | 2017

Comptes rendus des publications de 2011-2013
\end{abstract}

\title{
Maria Macuch, Dieter Weber, Desmond Durkin- Meisterernst (eds.). Ancient and Middle Iranian Studies
}

\section{Philip Huyse}

\section{(2) OpenEdition Journals}

Édition électronique

URL : http://journals.openedition.org/abstractairanica/41967

DOI : 10.4000/abstractairanica.41967

ISSN : 1961-960X

Éditeur :

CNRS (UMR 7528 Mondes iraniens et indiens), Éditions de l'IFRI

Référence électronique

Philip Huyse, «Maria Macuch, Dieter Weber, Desmond Durkin-Meisterernst (eds.). Ancient and Middle Iranian Studies », Abstracta Iranica [En ligne], Volume 34-35-36 | 2017, document 4, mis en ligne le 30 juillet 2017, consulté le 29 septembre 2020. URL : http://journals.openedition.org/abstractairanica/ 41967 ; DOI : https://doi.org/10.4000/abstractairanica.41967

Ce document a été généré automatiquement le 29 septembre 2020.

Tous droits réservés 


\title{
Maria Macuch, Dieter Weber, Desmond Durkin-Meisterernst (eds.). Ancient and Middle Iranian Studies
}

\author{
Philip Huyse
}

\section{RÉFÉRENCE}

Maria Macuch, Dieter Weber, Desmond Durkin-Meisterernst (eds.). Ancient and Middle Iranian Studies. Proceedings of the 6th European Conference of Iranian Studies, held in Vienna, 18-22 September 2007. Wiesbaden, Harrassowitz Verlag, 2010, X + 278 p.

(Iranica, Band 19)

1 Ce volume réunit une sélection de vingt-deux contributions de jeunes iranistes et de chercheurs confirmés dans le domaine des recherches sur l'Iran dans l'Antiquité et le haut Moyen Âge oriental, telles qu'elles ont été présentées lors de la sixième édition du Congrès des études iraniennes, organisé tous les quatre ans par la "Societas Iranologica Europaea" (SIE) depuis 1987. Le volume contient les études suivantes : Chiara Barbati, "The Christian Sogdian Manuscript C 5 as an Example of 'Translation Literature': Work in Progress" (p. 1-10). Alireza Askari Chaverdi and Pierfrancesco Callieri, "Preliminary Report on the Irano-Italian Stratigraphic Study of the Toll-e Takht, Pasargad. Investigations on the Material Culture of the Achaemenid and Post-Achaemenid Periods in Fars" (p. 11-28). Iris Colditz, "Zur onomastischen Erschließung der mitteliranisch-manichäischen Texte für das Iranische Personennamenbuch" (p. 29-42). Touraj Daryaee, "When the End is Near: Barbarized Armies and Barracks Kings of Late Antique Iran" (p. 43-52). Paolo Delaini, "The Strange Case of the Plant rivas. How the Middle-Persian Tree of Life Became the Protagonist of an Episode of Austrian History" (p. 53-60). Ela Filippone, "Xerxes Persepolis h, $\S 4$ in the Light of the Old Persian Information Structure" (p. 61-76). Tommaso Gnoli, "Mithras and the Stars: a Note" (p. 
77-86). Mohammad-Taghi Imanpour, "The Communication Roads in Parsa during the Achaemenid Period" (p. 87-98). Thomas Jügel, "On the Origin of the Ergative Construction in Iranian: Evidence from Avestan" (p. 99-114). Götz König, "Der PahlaviText Zand i Fragard $\bar{\imath}$ Juddēvdād" (p. 115-31). Maria Macuch, "Incestuous Marriage in the Context of Sasanian Family Law" (p. 133-48). Gabriele Puschnigg, "The Hellenistic Reception in the Pottery from Merv" (p. 149-60). Enrico G. Raffaelli, "Bundahišn 26 and the Pahlavi Sih-rōzag: Comparative Notes" (p. 161-77). Ulla Remmer, "Altiranische Namen in der Nebenüberlieferung. Elamisch Mi-za-pir-za-ka, griechisch 'A $\mu \nu \tau \iota \varsigma$ und die altiranische Sequenz -ava- in griechischer Vermittlung" (p. 179-90). Khodadad Rezakhani, "Balkh and the Sasanians. The Economy and Society of Northern Afghanistan as Reflected in the Bactrian Economic Documents" (p. 191-204). Adriano V. Rossi, "Élamite halmarriš vieux-perse didā- est-elle vraiment une forteresse ? (I)" (p. 205-18). Martin Schwartz, "Lexical Cruces of Yasna 29 and the Serial Cross-Textual Composition of the Gathas" (p. 219-24). Golfam Sharifi, "Étude des différentes sortes de paronomases dans les textes Pahlavis" (p. 225-29). Yuhan S.-D. Vevaina, "Hubris and Himmelfahrt. The Narrative Logic of Kay Us' Ascent to Heaven in Pahlavi Literature" (p. 231-43). Burzine K. Waghmar, "Preliminary Remarks on Bactrian Diplomatics" (p. 245-54). Dieter Weber, "Writing Exercises in Late Sassanian Times. A Contribution to the Culture of Writing Pahlavi" (p. 255-63). Chlodwig H. Werba, "The Title of the Achaemenid 'King'. Etymology, Formation and Meaning of Old Persian xšāyatiya-" (p. 265-78).

\section{AUTEURS}

\section{PHILIP HUYSE}

EPHE 